\title{
THE EFFECT OF INFORMATION SYSTEMS, COMMUNICATIONS AND CAREER DEVELOPMENT TO COMMITMENT IN MARITIME HIGHER EDUCATION INSTITUTE JAKARTA
}

\author{
Rosmayana \\ Aman Jaya Maritim Academic \\ Janna.69ftr@gmail.com
}

\begin{abstract}
This study aimed to determine the effect of system information, communications and career development of commitment to lecturer Maritime Higher Education Institute of Jakarta. This study uses a quantitative approach with survey methods and data analysis techniques using correlation analysis and path analysis (path analysis).Discussion: Affordable population in this study is a lecturer in Maritime Higher Education Institute of Jakarta with samples of 108 lecturer in Technique proportional random sampling of each program of study Maritime Higher Education Institute of Jakarta.The results showed that: (1) there is a direct positive influence on the commitment of information system; (2) there is a direct positive influence on the commitment of communication; (3) there is a direct positive influence on the commitment of career development; (4) there is a direct positive influence on information systems, communications, and career development together against of commitments.
\end{abstract}

Keywords: Information System, Communication, career Development and Commitment

Development of Indonesian human resources will be the key to success in national development because humans are actors, implementers as well as development targets that will determine the success or failure of national development implementers in all fields. One such area is the field of education. Education provides a view to looking into the future. Education is an investment for the future of the nation and can be designed to prepare qualified, qualified, and moral human resources.

Jakarta High School of Sciences (STIP) as an echelon II work unit within the Ministry of Transportation based on Presidential Decree No. 42 of 2000 on the School of Shipping Science and Regulation of the Minister of Transportation Number: KM.68 of 2009 on the organization and working procedures of Sekolah Tinggi Ilmu Sayar Has the task of organizing an academic education and / or vocational program in the field of shipping sciences, so STIP is an educational and training institution that conducts training with the characteristics of producing graduates who have high competence with academic or vocational degree and have a strong physical and physical supportive attitude, discipline, Responsibility and high integrity to his profession.

The process of marine education and training can be run when there is input in the form of candidate cadets and student officers from the community, shipping companies and government agencies. To produce quality output and competitiveness, it requires the training component in the form of: curriculum, faculty (lecturer), teaching aid (learning media), 
learning method and budget. From the above description of the most important and dynamic is the teaching staff (Lecturer).

In Law No. 14 of 2005 on teachers and lecturers of Chapter I Pasa 1 verse 2 which reads as follows: Lecturers are expressed as professional educators and scientists with the main task of transforming, developing and disseminating science, technology and the arts through education, Research, and community service.

In relation to this research, the results of pre-survey conducted in the field showed that research on STIP lecturers' commitment in teaching and learning activities at cadets and training participants still showed at the level that can not be achieved as expected. The problem is as follows:

Most of the lecturers of STIP Jakarta have not been optimally developed their career, the result of preliminary survey conducted by the researcher there are approximately $30 \%$ data lecturer STIP Jakarta lecturers lack understanding of existing information system and exist, low communicate lecturers (oral and written), not yet the development of career development Lecturers, lack of professionalism of lecturers, thus greatly hampering the increasing commitment of lecturers in carrying out their duties.Communication between lecturers and cadets in teaching and learning activities is not in accordance with the semester learning plan (RPS) and syllabus, due to the lack of lecturers face the rapid development of instructional media, technology and international and national regulations, resulting in commitment in the implementation of the main task is still less.

Most of lecturers STIP Jakarta still do not understand about information system either internally (simulator / laboratory) and external network (network in the form of email and website) or in other words lack of understanding about information technology which resulted communication with cadets in learning Substandard and well informed national and international IMO information regulations. To that end, lecturers should always try to develop their competencies in a sustainable way to be able to adjust to the demands of the dynamics of the development and the needs of education. Professional career development of lecturers can be done through education, study, research, scientific forum, communication forum, information technology, and other supporting activities, so as to increase the lecturer's commitment in carrying out its main task in order to produce professional and highly competitive seafarers.

So the researcher took the title of research as follows "Influence of information systems, communication, and career development towards the commitment of lecturers at Marunda Jakarta School of Marine Science". Researchers hope that the results of this study can provide suggestions and follow-up steps in maintaining the career development of lecturers to always be quality and quality so as to produce professional seafarers according to national and international regulations.

\section{Commitment}

Robbins (2016: 419), dkk states, "Unified commitment is characterized by the dedication to the team's goal and a willingness to extend the extraordinary amount of energy to achieve them. Members of an effective team exhibit intense loyalty and dedication to the 
team and are willing to do whatever it takes to help their team succeed ". Based on the above concept, a united commitment is characterized by dedication to the team's goals and willingness to deliver a tremendous amount of workforce to achieve team goals. Effective team members show intense loyalty and dedication to the team and are willing to do anything to help their team succeed.Colquitt, Jeffery A. Lepine, and Wesson (2013: 63) states, "Organizational commitment is defined as the desire on the part of an employee to remain a member of the organization. Organizational commitment influences whether an employee stays a member of the organization (is retained) or leaves to pursue another job (turns over) ". Based on the above concept, organizational commitment is defined as the desire on the part of the employees to remain a member of the organization. Organizational commitment influences whether employees remain members of the organization (retained) or abandoned to pursue other work (more turns).

L. Daft states "Commitment - Since all ideas are put on the table, people can ultimately achieve genuine purchases - around important goals and decisions." The meaning of this concept, commitment because all the ideas put on the table, people can finally achieve the original purchase - around important goals and decisions. From the description above commitment is a self-relation to duties and obligations that can be responsible and responsive, innovative attitude toward the development of science and technology.Based on the description of some of the above concepts can be synthesized commitment is the attitude of your loyalty to perform tasks voluntarily without coercion by exploring your potential and ability in performing important tasks. With Indicators: (1) loyalty, (2) volunteer to perform tasks, (3) explore potentials.

\section{Information Systems}

R. Kelly Rainer et al (2013: 25) states an information system collects, processes, stores, analyzes, and disseminates information for a particular purpose. As in the fourth edition of the book as follows "an information system collects, processes, stores, analyzes, and disseminates information for a specific purpose".

According to Kenneth C. Loudon and Janne P. Laudon (2016: 48) in his book states as follows: "An information system can be defined technically as set of interrelated components that collect (or retrieve), process, store, and distribute information to support Decision making and control in an organization ". According to the concept, an information system can be defined technically as a set of interconnected components that collect (or retrieve), process, store, and distribute information to support decision making and control within an organization.

Brian K. Williams and Stacey C Sawyer (2015: 430) stated "An information system is a combination of people, hardware, software, communication devices, and databases that process data and information for a specific purpose". So the definition of an information system is a combination of people, hardware, software, communication devices, and databases that process data and information for a particular purpose.

According to Gabriele Piccoli (2012: 28), information systems are formal, sociotechnical, organizational systems designed to collect, process, store, and distribute 
information, as in his book: "Information systems are formal, sociotechnical, organizational systems designed to collect, process, Store, and distribute information ".

Based on the description of some of the concepts described above can be synthesized information systems can be defined technically as a set of interrelated components that collect (or retrieve), process, store and distribute information to support decision making and control within the organization. With indicators: (1) a set of components (information technology equipment), (2) managing information (collecting, processing, distributing, storing), (3) decision makers, (4) control.

\section{Communication}

In the opinion of Richard West / Lyn H. Turner (2014: 5), "Communication is a social process in which employers establish and interpret meaning in their environment." According to the above concept, communication is a social process whereby individuals use symbols to construct and interpret meaning in their environment.

EM Griffin (2015: 6), et al, also stated, "Communication is a relational process not only because it takes place between two or more persons, but also because it effects the nature of the connections among the people". According to the concept, communication is a relational process not only because it takes an object between two or more people, but also because of the nature of the relationship between people.

According to Angelo Kinicki and Brian K. Williams (2016: 478), "Communication is the transfer of information and understanding from one percent to another". So what is meant by the concept, communication is the transfer of information and understanding from one person to another.

Based on the descriptions of some of the concepts described above can be synthesized communication is a process of transmitting meaningful information from one party to another through mutual interaction whereby individuals by using symbols that are understood can build and interpret meaning in their environment. With indicators: (1) Transmission process, (2) Meaningful information, (3) Use of symbols.

\section{Career Development}

Career development according to I Komang Ardana, Ni Wayan Mujiati and I Wayan Mudiartha Utama (2012: 117), "Career development is a personal improvement that a person undertakes to achieve a career plan and improvement by personnel deployment to achieve a work plan accordingly With the path or ladder of the organization ".

Career development by Leslie W. Rue, Nabil A. Ibrahim and Lloyd L. Byars (2016: 198), "Career development is an ongoing, formalized effort by an organization that focuses on developing and enriching the organization's human resources in light of both the Employee's and the organization's needs ". According to the above concept, career development is an effort with a forward and formal approach by organizations that focus on developing and enriching human resources in sustainable organizations for better and more focused in the career development of employees and organizational needs. 
Mondy and Martocchio (2016: 234) states the following: "According to the above concept, career development is an approach Formal organization used by the organization to ensure someone with the qualifications and experience available at the time of need.

According to Widodo (2015: 112), career planning and development, "Career planning, is a process whereby a person chooses career goals and career path that will be taken to achieve that goal. While career development is the development activities of personnel in order to fulfill the career plan chosen. Career planning and development provides a very important support to the smooth running of an organization ".

From some of the above conceptual descriptions, it can be synthesized that career development is the process of enhancing, developing one's skills through a series of human resource stages through a series of activities with a formal approach that contribute to exploring a person's career with appropriate qualifications and experience appropriate to organizational goals, available When needed with indicators (1) skills improvement, (2) qualifications, (3) experience, and (4) needs.

\section{METHOD}

This research uses quantitative approach with survey method and data analysis technique using correlation analysis and path analysis. Before performing correlation analysis and path analysis should be analyzed descriptive, normality test, and significant test of regression and regression linieritas test. Number of variables as many as 4 (four), namely information siatem (X1), communication (X2), career development (X3), and commitment $(\mathrm{Y})$, where research in STIP Jakarta. The affordable population in this study is the lecturer of the School of Shipping Sciences (STIP) Jakarta, amounting to 148 lecturers with a sample of 108 lecturers by Technique Propotional Random Sampling from each STIP Jakarta study program.

\section{RESULT AND DISCUSSION}

\section{Positive Direct Influence Career Development (X3) on Commitment (Y)}

The results of the fourth hypothesis analysis resulted in the finding that career development had a direct positive effect on commitment. Based on these findings it can be concluded that commitment is directly affected positively by career development. Increasing the career development of lecturers will result in the commitment of lecturers in carrying out their main tasks more effectively. The results of this study are consistent with the opinions of some experts including William J. Rothwell, Ph.D., DR. Peter Chee, and Jenny Ooi (2016: 87-88) put forward his theoretical, "Career planning and career counseling efforts. By investing in career-related issues, organizational leader of demonstrate care for workers. That builds an employment brand that displays the commitment that is authentic in helping individuals to maintain up-to-date skills in the face of changing employment conditions. That commitment, in turn, creates a foundation on which to build engagement and retain talented people ". 


\section{Positive Direct Influence of Information System (X1) on Commitment (Y)}

The results of the fifth hypothesis analysis provide findings that the information system has a direct positive effect on commitment. Thus it can be concluded that commitment is directly affected positively by the information system. Increased lecturer's understanding of information systems as learning media and technology will lead to increased commitment of lecturers in carrying out its main tasks. The results of this study are consistent with the opinion of some of the experts are Charles WL Hill's opinion, Gareth R. Jones and Melissa A. Schilling (2015: 132-133) put forward his theoretical, "Similarly, the theory behind Internet-based retailers such as Amazon.com Is that replacing physical stores and their supporting personnel with online virtual store and automated ordering and checkout processes allow a company to take significant costs out of the retailing system. Cost savings can also be realized by using Web-based information system to automate many internal companies activities, from managing expense reimbursements to benefits planning and hiring processes, thereby reducing the need for internal support personnel. A company's infrastructure - that is, its structure, culture, style of strategic leadership, and control systemdetermines the context within which all other value creation activities take place. It follows that improving infrastructure can help a company increase its efficiency and lower its cost structure. Above all, an approach infrastructure can help foster a companywide commitment to efficiency, and promote cooperation between different functions in pursuit of efficiency goals. For now, it is important to note that strategic leadership is important in building a companywide commitment to efficiency. The leadership task is to articulate a need for a company to focus on improving efficiency. It is not enough to improve the efficiency of production, or of marketing, or of $\mathrm{R} \& \mathrm{D}$ in a piecemeal fashion. Achieving superior efficiency requires a company to be articulated by general and functional managers. A further leadership task is to facilitate the cross-functional cooperation needed to achieve superior efficiency. For example, designing product that is easy to manufacture requires that production and R \& D personnel communicate; Integrating JIT systems with production scheduling requires close communication between materials management and production; And designing self-managing teams to perform production tasks Require close cooperation between human resources and production. Keep in mind that achieving superior efficiency is not something that can be tackled on a function-by-function basis. It requires an organizationwide commitment and an ability to ensure close cooperation between functions. Top management, by exercising leadership and influencing the infrastructure, plays a significant role in this process ".

\section{Direct Positive Influence Communication (X2) on Commitment (Y).}

The results of the sixth hypothesis analysis resulted in the finding that communication had a positive direct effect on commitment. Based on the findings, it can be concluded that commitment is directly influenced by positive communication. Increased communication smoothness between lecturers with cadets, lecturers with lecturers and lecturers with management will lead to increased commitment of lecturers in carrying out its main duties. The results of this study is consistent with the opinion of some experts of which 
are the opinions of Katherine Adams and Gloria J. Galanes (2012: 22) put forward his theoretical, "The way you interact with other group members succeed or fail and whether Your group outcomes are winners or train wrecks. Therefore, you must pay attention to your communication in groups meets the standards of ethical behavior we present here. In a small group, ethical behavior concerns members' willingness to communicate, treatment of fellow members, treatment of information, and commitment to the group ".

\section{Positive Direct Influence of Information Systems (X1), Communication (X2), Supervision (X3) on Commitment (Y)}

The results of the fourth hypothesis analysis resulted in the finding that the information system, communication, and career development together had a direct positive effect on commitment. Based on these findings it can be concluded that commitment is directly affected positively by the information system, communication, and career development together. Increasing the information system, communication, and career development of lecturers together will result in increased commitment of lecturers in carrying out its main tasks.

In this case, if one or all indicators of the information system, communication, and career development together with one or more indicators of commitment are to be found, there will be a positive relationship. It is therefore suspected that there is a positive influence of information systems, communication, and career development together towards commitment. This means that the higher the information system, communication, and career development the higher the commitment of the lecturer of Sekolah Tinggi Ilmu Sailing.

This is also supported by the results of research written by Faulinda Ely Nastiti, Husniati Mafatihus Solehah with the title alignment of information systems to meet business and research objectives written by F Andi Budi P, Patricia Dhiana Paramita, and Heru Sri Wulan with the title of the influence of career development And communication to employee commitment that impact on work productivity (case study employee at CV Tirta Minerva Semarang).

\section{CONCLUSION}

Based on the results of processing and data analysis and hypothesis testing can be summarized as follows; (1) Information systems have a positive direct effect on commitment; (2) Communication has a direct positive effect on commitment; (3) Career Development has a direct positive effect on commitment; (4) Information systems, communication, and career development together have a direct positive effect on commitment.

\section{REFRENCES}

Adams, Katherine, and Gloria J. Galanes, Communication in Group: Application and Skills, McGraw-Hill, New York, 2012

Barret, Deborah J.. Leadrship Communication. McGraw-Hill Education, New York, 2014. Bernardin, H. Jhon, et al, Human Resource Management, McGraw-Hill, New York, 2013. 
Certo, Samuel. C.. Supervision : Concepts an Skill-Building, McGraw-Hill, New York, 2013. Colquitt, Jason A, Jeffery A. Lepine, and Michael J. Wesson, Organizational Behavior : Improving Performance and Commitmen in the Workplace, McGraw-Hill, New York : 2013.

Colquitt, Jason A., Jeffery A. Lepine, and Michael J. Wesson. Organizational Behavior: Improving Performance and Commitment in the Workplace, McGraw-Hill, New York : 2015.

Daft, Richard L., Leadership, South-Western, Cangage Learning, Singapore, 2011.

Dessler, Gary, Human Resource Management, : Pearson Education Limited, Harlow, England, 2017.

Glickman, Carl D., Stephen P. Gordon and Jovita M. Ross-Gordon. SuperVision and Instructional Leadership : A Developmental Approach. Pearson Education, New Jersey, 2014.

Griffin, Em, Andrew Lebetter and Glenn Sparks. A First Look at Communication Theory, McGraw-Hill, New York, 2015.

Hill, Charles W.L., Gareth R. Jones, and Melissa A. Schelling, Strategic Management, Cengage Learning, Singapore, 2015.

I Komang Ardana, Ni Wayan Mujiati, dan I Wayan Mudiartha, Manajemen Sumber Daya Manusia, Graha Ilmu, Yogyakarta, 2012.

Ivancevich, Jhons M., Robert Konopaske, and Michael T. Matteson, Organizational Behavior \& Management, McGraw-Hill, New York, 2014.

Kinicki, Angelo and Brian K. Williams, Management: A Practical Introduction, McGrawHill, New York, 2016.

Leonard, Edwin C., Jr; Supervision: Concepts and Practices og Management, South-Wastern Cengage Learning, USA, 2010.

Loudon, Kenneth C. dan Janne P. Laudon. Management Information System. Pearson Education Ltd, Harlow, 2016.

Mondy, R. Wayne and Joseph J. Martocchio, Human Resource Management, Pearson Education Limited, Edinburgh gate, Harlow, 2016.

Piccoli, Gabriel. Essential of Information Systems for Managers. Jhon Wiley \& Son, Danvers, 2012.

Reiner, R. Kelly dan Casey G. Cegielski. Introduction to Information Systems. Edisi Ketiga, Jhon Wiley \& Sons, Danvers, 2011.

Robbins, Stephen P. and Mary Coulter. Management, Pearson Education Limited, London, 2016.

Rothwell, William J., Ph.D., The Leader's Daily in Tallent Management, McGraw-Hill, New York, 2016.

Rue, Leslie W. et al, Human Resource Management, McGraw-Hill Education, New York, 2016.

West, Richard and Lyn H. Turner, Introducing Communication Theory, Analysis and Application, Mc Graw-Hill, New York, 2014. 
Widodo, Eko Suparno, Manajemen Pengembangan Sumber Daya Manusia, Pustaka Pelajar, Yogyakarta, 2015.

Williams, Brian K., dan Stacey C. Sawyer, Using Information Technology, McGraw-Hill, New York, 2015. 